\title{
KULEUVEN
}

\section{Change in study programmes: the Low Countries}

The final publication is available at http://www.palgrave-journals.com/hep/journal/v17/n3/abs/8300055a.html

HUISMAN, J., J.C. VERHOEVEN \& K. DE WIT (2004) "Change in Study programmes: the Low Countries." Higher Education Policy. 17 (3) pp. 269-285. 


\title{
Change in study programmes: the Low Countries
}

\author{
Jeroen Huisman ${ }^{1}$, Jef Verhoeven ${ }^{2} \&$ Kurt De Wit ${ }^{3}$
}

\section{Introduction}

In the late 1980s and 1990s, both in the Netherlands and Flanders, debates took place on the organization of the supply of programmes of the university sector as well as the higher professional education sector (hogescholen). Of central concern for both national governments was the perceived lack of efficiency in the total supply of programmes. In this article, we describe which policies and instruments the governments put forward and enacted to realize its objective of increasing efficiency. We concentrate on the policies and instruments for the university sectors in the two countries. A second objective is to analyse how universities reacted to the proposed and implemented policies. Comparing the similarities and differences between the policies and reactions to the policies and instruments is - given the similar problem the governments are confronted with — an assignment worthwhile to pursue.

The structure of this article is as follows. First, it elaborates upon the efficiency problem and formulates our expectations concerning the differences in policies and instruments as well as the reactions of the universities. Then it describes the developments in the two countries. For both systems, the prelude to the policy problem, the search process for solutions in the sphere of power between the stakeholders, the actual solutions implemented and the reactions of the universities are examined. The concluding section reflects on the expectations.

\section{The transparency problem in context}

At the end of the 1980s, the Dutch and Flemish governments expressed serious concern about the efficiency of the programme supply. In the Netherlands, policy-makers labelled the issue as the problem of transparency. In Flanders, the issue was termed an optimization problem. The general abstract concern regarding efficiency can be explicated thus: in the second half of the 1980s, both higher education systems experienced a considerable growth of study programmes. The phenomenon materialized both at the universities and the hogescholen. The governments had doubts as to whether students were able to select the programme that fitted their expectations and whether employers could choose the graduates who best fitted their needs and wishes.

Furthermore, the governments doubted as to whether the universities' intentions to set up new programmes were really driven by needs of students and the labour market or by in the eyes of the government — less desirable motivations such as expansion and drift

\footnotetext{
${ }^{1}$ Center for Higher Education Policy Studies, Universiteit Twente, Netherlands

${ }^{2}$ Centre for Sociology of Education, KU Leuven, Belgium

${ }^{3}$ Centre for Sociology of Education, KU Leuven, Belgium
} 
(setting up programmes outside designated areas). Unappreciated by the government at the time, the funding mechanism of higher education in fact induced universities to expand their supply. The level of funding largely depended on the number of students enrolled. Attracting students - either by copying a (perceived) successful programme of another organization or by launching a new programme - became a major survival strategy for establishments of higher education.

The governmental ideas about transparency and optimization may be assumed to run counter to the wishes and expectations of individual higher education organizations. Our hypothesis with respect to the universities' reactions to the policies is rather straightforward. Given that the interests of the parties involved in the transparency issue diverge, we anticipate that the reaction will deviate from the objectives and expectations of the government. Furthermore, one may anticipate that solutions all parties agree upon are not easy to find; finding solutions will be a long and troublesome process. These expectations are even strengthened by the notion of there being a considerable distance between the government (formulating the policy) and the relatively autonomous professionals who implement educational change at decentralized levels within the organizations (Van Vught, 1989; Jenniskens, 1997).

The conflict of interests constitutes one of the (major) elements in the institutional context of the policy problem and policy formation. The institutional approach stresses that context in which policies and instruments take shape, affects both those policies and instruments. Next to the element of conflicting interest, the steering model can be considered as a weighty aspect of the higher education organizations' context. For institutional theorists (March and Olsen, 1989; Scott, 1995; for an elaboration in higher education Gornitzka, 1999), the content and implementation of policies are influenced by the institutional and historical context. System characteristics such as the government's steering model are important to focus upon because they are assumed to mediate, constrain and facilitate both policy formation and organizational response. Accordingly, we will first set out the state steering philosophies (based on the work of Olsen's (1988) distinction between the sovereign state, the institutional state, the corporate-pluralist state and the supermarket state) in the Netherlands and Flanders.

\section{The Netherlands}

\section{Steering model}

The Netherlands may be held up as one of the first countries in Western Europe - but in a totally different vein as another 'leader': England - attend to the question, 'which steering model and instruments are necessary to achieve the government's objectives for higher education?' Until the mid-1980s, the steering model for universities could be (see Gornitzka et al. 1999) qualified as the sovereign model. The government 'controlled' the universities through regulation, planning and funding mechanisms, but in the domain of teaching and research activities, universities had considerable leeway. The corporatepluralist model was visible, to some extent (see also Lijphart, 1968). From the mid-1980s, the government gradually stepped back, leaving more initiative to the universities. At the same time, the government retained ultimate responsibility for the quality of higher 
education and efficient and effective spending of public resources. In general, the government moved away from setting the conditions to focusing more on the outcomes. Hallmarks in the drive towards more autonomy were the 1985 white paper Higher Education Autonomy and Quality (HOAK) and the 1993 Higher Education and Research Act (WHW). The HOAK white paper announced the withdrawal of the government in favour of organizational autonomy. The two most important areas touched upon in the HOAK white paper were quality assurance and programme supply (see below). The 1993 WHW was the legislative consequence of the idea of increasing autonomy with the government steering from a distance.

In terms of Olsen's state models, the Netherlands gradually evolved towards the supermarket model. This is confirmed by the 1990s policy documents. In both style and language used in these documents - students as consumers and clients of higher education, organizations operating in markets of teaching of research, knowledge becoming the product of higher education, university administrators becoming public managers, achieving level playing fields between public and private providers of higher education - all reveal the drive towards the supermarket model. In the late 1990s, characteristics of the corporate-pluralist model were still visible. Thus, during the process of drawing up of the draft Higher Education and Research Plan 2000, the minister had numerous contacts with stakeholders in higher education to exchange ideas, to consult interest groups, to reach consensus over objectives and to negotiate suitable instruments.

\section{Policies for the supply of programmes}

The development of policies regulating the supply of study programmes hewed to a different path from that of higher education policy in general. From the 1960s, universities had the choice of implementing an academic, an experimental or a free study programme. An academic programme was a programme included in the Academic Statute, a list of approved study programmes. A university needed ministerial approval for such a programme. For an experimental programme (not yet taken up in the Academic Statute) ministerial approval was also necessary, plus the advice of the Education Council and the Academic Council, two formal advisory bodies in educational matters. A free study programme required only the approval of the internal decision-making bodies of the university. While the intentions in the 1980s (HOAK White Paper) were to grant the universities autonomy to establish new programmes within the disciplines designated to the organizations, the 1993 WHW regulations were not in keeping with these intentions. The impressive growth in the number of programmes in the higher professional sector challenged the hopes of the minister as to whether effective self-regulation could be attained. Under Parliamentary pressure, the minister changed the initial regulations and set up the Advisory Committee on the Supply of Programmes (ACO). New Programme initiatives were to be sent to the ACO. This committee advises the organizations about their initiatives. Of particular concern for its judgements, the ACO evaluates the impact of the organization's proposal on the overall efficiency of supply at the system level (macro-efficiency). The Minister of Education, Culture and Sciences is supposed to accept the ACO's advice, unless weighty counter arguments can be found. After the Minister's final approval, the programme is presented for inclusion in the Central 
Register of Study Programmes (CROHO). For public universities, inclusion in the CROHO implies governmental funding. In the eventuality that a study programme would harm macro-efficiency (e.g. poor quality, indicated by the national quality assurance system), the Minister can decide - after warning the university concerned - to withdraw the programme from CROHO.

With these new regulations introduced, the debate on the transparency of the supply was far from over. The new regulations were certainly effective with respect to generating of new programmes. The number of programmes annually proposed by universities since 1993 were relatively modest - particularly when compared to the period from the mid1980s to 1993. The majority of the initiatives received a negative opinion from the ACO, with which the Minister usually concurred. However, the regulations had no impact on the existing 'stock' of programmes. Complaints from employers' associa-tions and professional organizations about transparency persisted. The universities' buffer organization VSNU (Association of Dutch Universities) moved upon improving transparency in the supply of programmes. In 1996, the Veldhuis Committee recommended clustering university programmes. Related programmes were brought together under common labels, which eventually resulted in some 124 generic programme groupings emerging in 1998.

\section{Responses of the two universities}

Both Dutch universities studied are regional establishments. University A is one of the smallest in terms of student numbers, built in the 1960s, focusing on engineering and social sciences. University B is one of the oldest and classic universities, providing a broad variety of disciplines: natural sciences, humanities, social sciences, economics and health.

\section{University A}

University A developed a profile as an entrepreneurial two-core university, those being the two disciplines of central concern - engineering and social sciences. The more explicit attention to the latter core had its origin in the idea — already present when the university was founded - that engineers needed a broader education than solely skills and knowledge rooted in engineering. A considerable amount of social science courses were injected into the engineering study programmes. In 1976, the first full-blown social science degree programme was established, followed by two others in the early the 1980s.

The latter half of the 1980s was relatively quiet at University A in establishing new programmes. Just before the implementation of the 1993 regulations, the university and its faculties became more active. This was not a unique event - most universities developed and launched many new programmes in the period 1989-1993, a move clearly anticipating the more strict regulations that came into force from 1993 on (see also Huisman, 1995). University A established four programmes in 1992 and 1993, one being a social science programme and three engineering programmes with a strong ties to social science issues (management, environment, information, commu-nication). The programmes were former specializations within existing programmes. 
After 1993, ideas developed for new programmes, but were not realized until 2000 with a programme in Telematics. This is far from saying that in the interval, innovation was absent. Whereas in the late 1980s and beginning of 1990s weighted rested on new programmes, in the 1990s it was more inwardly turned. Stricter regulations caused universities to think again about expanding programme supply. At the same time, educational innovation and improvement were held necessary by the university, especially in times of (predicted) decline in student numbers for the university sector and increasing competition between establishments. Quality assurance in education assumed greater weight from the mid-1980s on. To guarantee a sufficient level of quality for the programmes, organizational attention was needed. Moreover, educational innovation other than the establishment of new programmes were stimulated through an internal allocation scheme. Projects involving project-based learning and the development of telelearning, for instance, were financially supported by the Executive Board by matching budgets.

International developments represented another important external factor shaping the university's educational policies. In the late 1990s, the university adopted a Major-minor model — in the Anglo-Saxon tradition — for its study programmes. This development was not justified wholly by internationaliza-tion, but also because it was expected to attract more students. In line with ideas then circulating about internationalization and international comparability, the university (together with the other engineering universities) lobbied extensively — and successfully — in the1990s to extend the nominal duration of engineering programmes from $4-5$ years.

Developments at University A can be summarized as follows. Until the beginning of the 1990s, it gradually expanded its supply of programmes. From 1993 onwards, with the broadening of the supply of programmes virtually impossible, the establishment focused on other aspects to maintain or improve its attractiveness in times of falling student numbers: quality assurance and improvement mechanisms were introduced, internationalization stimulated, programme structures were adjusted (Major-minor, 5year programmes) and educational innovation was financially supported.

\section{University B}

At University B, a similar evolution was discernible in the period prior to 1993. Between 1989 and 1993, 14 new programmes were established. Similar arguments as at university A - (presumed) decreasing student numbers and rising competition between universities - played a dominant role. That there were more new programmes than at university A stems from larger scale and comprehensiveness of university B. Furthermore, university B had accumulated some experience in the 1980s as a response, by establishing new programmes to the government's cuts. In 1983 and 1986, the government closed down a number of departments and study programmes to reduce expenditure on higher education. For university B, 10 programmes vanished.

University B was especially successful in expanding its programme supply at the intersection of natural sciences and engineering. The university took the view that distinctions between the two disciplines were somewhat artificial. Half of the new 
programmes established blurred the boundary between the disciplines. Concerted action preceded the development of these programmes. The Executive Board established a working group on Technical Studies in 1988 to come up with ideas in this area. The implicit spur behind the working group was the Ministerial threat, present in the 1988 Higher Education and Research Plan, to close down natural sciences and engineering programmes with small student numbers. Some Euro 500,000 equivalent was set aside to carry out some of the plans in the report. By 1993, seven technical programmes were realized and implemented.

After 1993, university B embarked on scarcely any new initial programmes, with the exception of reviving a programme abolished in the 1980s. Here too, university B, greater attention to educational quality issues was evident. In addition to the national quality assurance system, the university introduced an internal system, which required faculties regularly to report on their evaluation activities and on the follow-up of recommendations by national visitation committees. In its regular meetings with the Faculty Boards, the Executive Board discusses such issues as completion rates, the quality of supervision and the 'do-ability' of study programmes.

Over and above quality issues, the search for new student markets was worth noting at university B as well. Already in the 1980s, a foundation to coordinate all postgraduate educational activities (courses, professional programmes) was created, and in the late 1980s, the university introduced two short-cycle programmes (2-year programmes). A final category of students of which the university focused on are the elderly. A special organization was set up to develop and coordinate education for this group.

\section{Flanders}

\section{Steering model and policies concerning the supply of programmes}

The reform of 1988-1989, made Belgium a federal state, with authority for education granted to the Communities. It also gave rise to a different model of governmental control of the university. Before 1989 , state universities were centrally managed to a high degree. They came directly under the responsibility of the Minister of Education, who was the organizing authority of state education. The decisions were executed by the administration, which was politicized. Moreover, strong centralism ('Brussels' took all decisions) went hand in hand with a high degree of bureaucratization.

The free universities were relatively autonomous, although, like state universities, they were controlled by a state commissioner. The government was reluctant to regulate, so as not to upset the delicate ideological and linguistic balance in the university sector. Indeed, the working of a consociational democracy (Lijphart, 1968; Verhoeven, 1982) in Belgium required deliberation and prudence by the different parties to keep the peace between different interest groups.

Given the particular position of state universities and free universities, it is impossible to site the relationship between universities and government in Belgium prior to 1989 in terms of only one of Olsen's categories. Policy towards state universities may be 
described as a sovereign state model. Control by the state, together with decision-making power in the hands of the government, were the main characteristics of this model. The model of the institutional state, with universities responsible for protecting academic values and tradition against one-sided interests of political regimes and interests groups, applied to free universities. Even so, governmental steering of both types of universities also possessed features from the segmented state model. Indeed, corporate bodies used their influence to promote the interests of their members. Thus, for instance, the discussions that changed the structure of university administration in 1970, witnessed negotiation conducted between deliberation vice-chancellors, professors, students, trade unions and other interest groups.

Already in the 1980s, the Minister of Education expressed misgivings with this structure, especially in the treatment meted out to state higher education, a view shared by many in university and in political parties. Hence, a fundamental shift emerged when Flanders obtained authority over education. With the Decree on universities of 12 June 1991, the Flemish government took an important step towards far-reaching university autonomy. The decree only exerts formal requirements in the fields of study, length of the course, division in cycles and so on; educational content — the course programme - may be decided by the universities.

However, the government did not withdraw entirely: 'The government creates conditions and sets out quality goals' (Van Den Bossche, 1995, 9). These conditions were — and are today - very often experienced by universities as barriers, cutting off the path to development. For instance, universities are required to follow strict rules in the appointment of teaching staff to different ranks, although the rules were softened recently. The government also organizes a meta-evaluation of the quality assurance processes, which according to the decree, the universities organize. Finance is strictly related to the number of students in the universities, differently weighted according to the field of study. A government commissioner reporting to the Minister of Education controls each university to ensure that the university does not take decisions that are not in keeping with the law.

Governmental steering of higher education after 1989 differs greatly from the period before. With the decree of 26 June 1991, former state universities became their own organizing body. Their autonomy became largely the same as that of free universities. On the other hand, free universities lost parts of their former freedom since the government wanted a guarantee they would act within the legal framework.

The new steering model is close to a market model. The government provides only the financial means, which it controls a posteriori. However, since autonomy is not total, the market state model applies to the current situation only partially. Furthermore, aspects of the segmented state are still visible in the steering model, and emerge in the different advisory councils present in the policy network.

One of the main purposes of the University Decree of 1991 was to bring proliferation of new courses in universities to a halt. Universities were subsidized according to student numbers. It was important to find new niches in the labour market and create new courses 
and to draw in new entrants. This brought about tremendous growth in the number of courses that made the academic landscape for students less transparent. The new decree prescribed which study areas could be provided by which university in order to keep the course supply transparent.

Another move against new courses proliferating was taken in 1995, when the social democrat Minister of Education entrusted a government commissioner, former vicechancellor Dillemans, to find a solution for this problem. Although not binding, in many universities discussions started about the consequences that followed from Dilleman's proposals. They did not lead to changes of importance.

Two important changes did take place and they did have consequences for student numbers, although not the supply of courses. The first established an entrance exam for students in medicine and dentistry. The second was a move by the Flemish government to reduce the number of graduates in physical rehabilitation and physiotherapy, trained at universities and colleges of higher education (hogescholen). This cut followed from a decision by the Belgian national government to reduce the numbers of medical doctors and physiotherapists because the growing number of graduates could no longer find posts in the overexpensive national health system. Universities agreed to these proposals provided that the subsidy to medical schools would not be touched. The Minister of Education's bid to divide tasks more rationally between universities and colleges of higher education in the area of physiotherapy was not accepted. Both institutions offer programmes that lead on to the same profession.

Save in these two instances, the government did not interfere directly in the attempts of the universities to expand their student numbers. Nevertheless, the Flemish government considered it important to rationalize course supply, because within the European context it wants its universities to be competitive. The Flemish government sought to rationalize and optimize by proposing that the universities consider improving current programmes, the rejection of inferior courses, 'freezing' (i.e. abolition but with the possibility of revival later) the closing down of courses, and in others, their merger. The instruments to achieve these goals are legislation and (mainly) information. The government tries to manage 'by talk', rather than obliging universities to take a particular direction.

Sometimes other routes are taken. Thus, for instance, since 1998 advanced academic courses 1 are financed, but the financial support is limited and depends on the number of advanced course diplomas granted by the university (output finance).

Although the Flemish government created more rules for universities than before 1991, and seeks to rationalize the course supply in order to have 'valuable' universities (Van Den Bossche, 1998), it urges them to be more entrepreneurial and dynamic and sets only the limits within which universities act.

\section{Responses of the Two Universities}

While the Flemish government stimulated universities to be entrepreneurial, it cut the possibilities for them to offer new courses. This was - and still is - a precarious situation for the universities. Although expected to provide courses that reflect the 
development of science and society, universities were often admonished to continue the programmes they provided at the start of the decade past. Indeed, the pressure to attend to economic development, to the internationalization of education and the development of new technology was stronger than ever. Although the Flemish government did not inveigh on the economic element of university education, universities became aware of the new economic liberalism in Europe (Van Heffen et al., 1999). Universities since long have an international orientation. However, the development of a unified Europe underlines this international vocation more than ever.

How did universities react to this government policy for more transparency and optimizing university courses? This question draws on two case studies of two major universities of Flanders, a large, old university (C) located in the centre of the country, and a large university (D), founded in the 19th century in the west of the country. The first is a free university, the second a state university.

\section{University C}

University $\mathrm{C}$ has not developed a real policy for promoting new programmes. In keeping with the line laid down by central university governing bodies on decentralization, new programmes were only occasionally developed by the central level. Two examples of programmes are to hand for which the central level, and more precisely the vicechancellor, took the initiative. Even so, establishment of the programme lay with the faculties. In 1994-1995, a lecture series was launched the idea to present, in 15 lectures, an examination of challenges about structural breaks in history, world view and science at the start of the 21st century. In 1997-1998, another series of lectures was established as elective course in the second 2 and third cycle to prepare students for entrepreneurship. Lectures were presented by business men (who also played a role in the exams), some lectures about the firm and the drafting of a business plan for an innovative business project.

Alongside these two examples, in 1989-1990 ran another initiative, begun by the vicechancellor, and involving all Faculties, named Operation Rationalization. Its goal was to enhance the quality of education in the first and second cycle, by limiting the number of courses, by reducing the volume of the courses and leaving behind the old notion of an 'encyclopaedic education'. This undertaking lasted some years.

These few examples apart, all changes to course content of the course took place at a decentralized level, within the faculty or department. The faculties are responsible for the organization of the courses. The dean has a managerial role, while Permanent Educational Committees are responsible for preparing, coordinating and evaluating the courses. The final decision is taken by Faculty Council.

There is (almost) no direct steering by central university administration. The latter defines general policy lines and tries to convince the decentralized actors to follow them. As faculties are represented in a number of central bodies, such central guidelines are not simply created at the top and then disseminated over the faculties. They are rather the product of discussion among both central actors and faculties. 
The work of the Permanent Educational Committees should be seen in this context: at the central level of the university a framework is developed to facilitate, support and stimulate their activities. Central financial incentives with faculty matching are regularly used as a lever for educational improvement and innovation, for example, for buying new teaching equipment.

The interaction between the central university level and the non-central level can best be described as follows. The non-central level enjoys a large amount of autonomy for curriculum development. Change, however, is top down from the central level. The lower level implements the change, which does not happen unless the non-central level agrees after thorough discussion and debate. Direct action or intervention by the university administration on the non-central level is an exception.

In all councils of the university independent academic personnel, auxiliary academic personnel and students are represented. External stakeholders participate only in the Board of Directors, which has no direct educational authority. External stakeholders play a role in educational matters only as invited members of Permanent Educational Committees. Most Permanent Educational Committees use the possibility to invite an alumnus as member.

Since the university decree did not authorize new courses to start and the government was not sufficiently generous to support new advanced courses, the new course development was effectively blocked. Nevertheless, prior to 1994 many faculties established advanced courses to keep up with development of knowledge and social demands. This too was stopped later. After 1998, however, new advanced programmes were created once new government finance was forthcoming. Yet, for many new programmes the margin of manoeuvre was limited because universities had to make agreements within the framework of the Flemish Interuniversity Council (VLIR).

The major changes in programmes reduced the number of courses in the first cycle and differentiated the second cycle. Often such measures were related to the start of a new quality assurance system (determined by the university decree), based on self-evaluation and (international) peer review. In turn they brought about improvements in programmes, while introducing new teaching methods (for instance, self-study assignments), which drew upon the help of a special bureau.

The procedure followed by most faculties was very similar. If an individual staff member sees an opportunity to develop a programme or make some appropriate changes to existing programmes, he seeks to sway his colleagues. The proposal is discussed in an ad hoc working committee, then introduced into the official procedure: first, via the Permanent Education Committee and later via Faculty Council. Debate is possible. In some faculties, a proposal does not proceed to Faculty Council unless it has the approval of the Permanent Education Committee. Finally, it requires to be approved by Academic Council. The approval of Faculty Council and Academic Council is problematic only when there is no agreement for the proposed innovation.

\section{University D}


As a state university, D has a special relationship with government. Before the special decree of 1991, much of its finances were controlled by the Minister of Education. The Minister also intervened in the appointment of academic staff, clerical staff and members of the Board of Directors. Finally, he could define by law the structure of the university.

The decree of 26 June 1991 transferred the organizing authority for academic education to University D. The university became an autonomous institution. Nevertheless, the Flemish government has greater possibilities to intervene in a former state university than in a free university. Supervision is exercised through the Government Commissioner, as in other universities, but it may also be exerted through four representatives on the Board of Directors who are appointed by the Flemish Parliament, in keeping with the university's profile. Although representatives of the social partners are members of the Board of Directors, their influence is rather indirect.

Developing new programmes is not the task of central level at university D. The Management Committee discusses proposals for new programmes only when they come from the Educational Committees via the Faculty Councils. Over the last few years, however, the central level pays much attention to educational innovation (including technological innovation), even if such innovation is primarily a task for individual professors, departments and educational committees.

The special decree of 1991 stated that organizing and coordinating educational provision is the responsibility of the faculty. The university subscribes to this principle. Its mission statement says that the university 'Opts for a decentralized, dynamic organization model'. The university sets out to develop a clear profile in the Flemish educational landscape, starting from its pluralistic character, and emerging gradually in its own specific educational concept, with more interactive educational methods and more variety in the educational supply, so that target groups other than the 'traditional' student (just finished secondary education, full time) may be catered for.

The mission statement has been implemented by developing a decentralized organizational model. Initiative lies with the faculties. The central level supports these initiatives (if necessary, also financially). The top does not intervene in the area of course content. The central level determines only structures and procedures. It provides guidelines, which define strategic options. Within these guidelines, the faculties can define more specific goals and the way to reach them. Recommendations made by faculties to the academic authority are rarely contested. If comments at central level are sent down to faculty, they concern mainly technical issues.

Besides parliamentary and economic stakeholders, only present in the Board of Directors, a representative of staff and students is member on most decision-making councils in the university. Since the Board is not responsible for course content, the influence of external stakeholders on courses is rather indirect. On the other hand, the Educational Council, an advisory council at a university wide level, may invite external experts. More direct influence from external stakeholders is seen in the faculties. Some Educational Committees invite alumni with special expertise in the world of work, to help update a 
course. Such involvement of alumni and business people in curriculum reforms is growing.

In reality, innovation in courses is, as with university $\mathrm{C}$, largely the result of initiatives by individual professors. They find support among their colleagues and, from then on, follow the formal procedure until agreement is attained at faculty level. Once decided at that level, the proposals go up to the Board of Directors, which has to decide about its implementation and execution.

As other universities, university $\mathrm{D}$ fell in with the constraints of the university decree: no new courses were established and only a few advanced courses, created. Still, social and economic advance demand their continuous updating. The establishment by decree of the new quality assurance system accelerated changes in some courses. Teaching methods stimulating independent work of students (e.g. case studies, reading lists, self-study assignments, exercises) were introduced; practical training, and in some faculties, the semester system, were also introduced

Looking at the procedures to bring about these changes, the role of Education Quality Units and Educational Committees in the faculties was very important. Although most innovations are the initiative of one or more professors, these proposals have to be accepted by these councils. There is no great direct external influence. Yet, some faculties mentioned contacts with alumni, with professional bodies and with industry. These groups have no direct influence on the programme innovations, however. Regular reviews have different influence on faculties, more in relation to 'how to teach', than to course content. Perhaps the strongest external influence may be found in the Faculty of Medicine. It is not an external group that urged the faculty to make major change to the curriculum, but rather, the orientation of the medical profession towards societal developments. Maybe the most important factor in this specific instance was the openness of the faculty to take societal developments as a reference point in constructing a new curriculum.

\section{Summary and Reflection}

The two Dutch universities - alert to the changing regulations, themselves less advantageous for programme innovation - introduced a number of new programmes just before 1993. Here, clearly the sharp distinction between the government's and the institutions' view on external and internal effectiveness and efficiency was at stake. Once the regulations were introduced in 1993, the universities' latitude disappeared. From then on, establishing new programmes was much more difficult either to convince the ACO or the Ministry that the proposal was not detrimental to systems-level efficiency. The universities explored other strategies to survive in a more competitive environment where student numbers were falling. The universities embarked upon three other general strategies: maintaining and improving the quality of the supply, bringing about other types of educational change within the programmes and finally aiming at types of students other than the 'traditional'. 
To reorganize the existing provision of programmes, the government realized that addressing individual universities would not be successful (given the diverging views on internal and external efficiency and effectiveness). Bringing in and engaging the VSNU in this operation seemed a wise strategy. Eventually, it led to relabelling of families of study programmes.

Until 1991, Flemish universities, and certain free universities, could easily initiate new courses, a move important for attracting new students. Students, in their turn, were important because universities were financed in large part according to student numbers. Even so, the government had doubts about the transparency of the course supply for the students, and by decree, excised the freedom of universities to start new basic academic courses. Since the decree did not limit the creation of advanced academic courses, universities created large numbers of new ones. In 1994, the budget for advanced academic courses was also cut, and the creation of new courses stopped. In the interval, a new quality assurance system, laid out by decree, started. Faculties took advantage of these new procedures to adapt their programmes and/or to improve the teaching methods. The two universities founded special units to introduce new teaching methods.

Although the universities were required to accept the limitations the decree imposed, there was considerable opposition even so, which came mainly from small universities. Both university $\mathrm{C}$ and $\mathrm{D}$ are large institutions. Together, they attract about $71 \%$ of all Flemish university students. Although most universities expanded during the past decade, the two big ones retained their lead. Opposition grew among other universities. First, a small university appealed against the decree reducing financial support for advanced academic courses. In 1998, the government even offered new support for a regulated development of advanced academic courses. Second, the government charged a commissioner to come up with an agreement between universities about opening some new courses in the smaller universities and reducing the oversupply of courses in particular study areas. Although the Commissioner presented his final report in November 1999 to the Minister of Education, and although some faculties had discussed the possible consequences of these proposals for their programmes, the report remained without political consequence. The government policy statement of 1999 stated its intention to keep the old limitations. The way to new courses was possible only if the university involved were to offer a placatory victim by abolishing a course already established.

Clearly, there was governmental pressure to improve the efficiency of programme provision. Universities used what leeway remained them to expand their supply (in the Netherlands just before 1993, in Flanders in the area of advanced courses). When the opportunities to expand the supply were brought to a halt, the universities seemed to turn towards internal processes, among which were quality improvement and adjustment to the labour market.

The relationship between the (changing) steering philosophy and the choice of policies and instruments is difficult to unravel. In the Netherlands, the relatively strict 1993 regulations for establishing new programmes are to a considerable extent at odds with development towards the supermarket model. On the other hand, in 1999, the Minister 
announced the abolition of the ACO and pleaded for more self-regulation. From this point of view, policy developments and instruments in force from the beginning of the 1990s until 2000 can be seen as an anomaly in period of transition. This transition turns around implementing policy instruments along the lines of a combined edition of the supermarket and the corporate-pluralist model. In a similar vein, regulations in Flanders do not seem to fit the concept of the 'supermarket' steering model, either. The debate on the supply of programmes has not yet been concluded in terms of government policies. It would appear that it is not so much the difference in views between institutions and government that accounts for the lack of policy initiatives. Rather, it seems that inter-relationships between universities (in particular between the larger — defending their status — and the smaller institutions - trying to obtain a larger share of the national programme supply) was constituted as an important undercurrent in the debate on programme provision. In this respect, future research into the impact of institutional context on policy formation should take more the composition of the institutional network of stakeholders into account rather than focusing on the steering model alone.

\section{Notes}

1 Advanced academic courses (third cycle courses) are courses following after the basic academic courses and are designed to broaden the knowledge gained from a basic academic course (complementary courses) or orientated towards specialization in a given area of study (specialist courses). In general they take 1 year of study.

2 Each basic course is split into one or two cycles, each comprising 2-4 years of study, depending on the subject. 


\section{References}

Dillemans, R. (1999) Optimalisering Universitair Aanbod in Vlaanderen. Derde rapport voor de Minister van Onderwijs, Brussel: Departement Onderwijs.

Gornitzka, $A^{\circ}$. (1999) 'Governmental policies and organisational change in higher education', Higher Education 38: 5-31.

Gornitzka, A ., Huisman, J., Heffen, O., Klemperer, A., Maassen, P., van de Maat, L. and Vossensteyn, H. (1999) State Steering Models with Respect to Western European Higher Education, Enschede: CHEPS.

Heffen, O., van, J.C., Verhoeven, K. and De Wit (1999) 'Higher Education Policies and Institutional Response in Flanders: Instrumental Analysis and Cultural Theory', in B. Jongbloed, P. Maassen and G. Neave (eds.) From the Eye of the Storm. Higher Education's Changing Institution, Dordrecht, Boston, London: Kluwer Academic Publishers, pp. 263-294.

Huisman, J. (1995) Differentiation, Diversity and Dependency in Higher Education, Utrecht: Lemma.

Jenniskens, I. (1997) Governmental Steering and Curriculum Innovations. A Comparative Study of the Relation between Governmental Steering Instruments and Innovations in Higher Education Curricula, Utrecht: Lemma.

Lijphart, A. (1968) The Politics of Accomodation: Pluralism and Democracy in the Netherlands, Berkeley: University of California Press.

March, J.G. and Olsen, J.P. (1989) Rediscovering Institutions, New York: The Free Press.

Olsen, J.P. (1988) 'Administrative Reform and Theories of Organization', in C. Campbell and B.G. Peters (eds.) Organizing Governance, Governing Organizations, Pittsburgh: University of Pitssburgh Press.

Scott, W.R. (1995) Institutions and Organisations, Thousand Oaks: Sage.

Vanderpoorten, M. (1999) Beleidsnota: Onderwijs en Vorming. 2000-2004, Brussel.

Verhoeven, J.C. (1982) 'Belgium: Linguistic Communalism, Bureaucratisation and Democratisa-tion', in H. Daalder and E. Shils (eds.) Universities, Politicians and Bureaucrats, Cambridge: Cambridge University Press, pp. 125-171.

van den Bossche, L. (1998) Optimalisatie universitair aanbod in Vlaanderen, Besluitvorming n.a.v. de besprekingen met de rectoren en minister L. Van Den Bossche van het eerste voortgangsrapport van ere-rector Dillemans, Brussel: Departement Onderwijs. 
Van Vught, F.A. (ed.) (1989) Governmental Strategies and Innovation in Higher Education, London: Jessica Kingsley. 